\title{
ACKNOWLEDGMENTS
}

My work on western French stained glass found its conception in an interview with Louis Grodecki at Columbia University in 1959, and its nurture in the lifework, generosity, and friendship of Jean Lafond. It is dedicated to Robert Branner, role model whose fundamental impact is best summed up in the phrase: he taught by doing.

My work on Saint-Père de Chartres was supported by predoctoral grants from Colum. bia University in the 1960s. I am grateful to the National Endowment for the Humanities for a summer stipend in 1970 , when primary research and site work were extended to other monuments, and then for a fellowship year in Paris (1976) when the book was structured and most of the work done on Le Mans and the problems of Chapter I. The American Philosophical Society provided grants from the Penrose Fund for work on Vendôme (1972) and on Sainte-Radegonde in Poitiers (1977); Syracuse University's Faculty Research funds supported the work on Dol (1978) and for writing in 1980-81. I am grateful to the American Council of Learned Societies for grants-in-aid for the work on Evron (1970), Sées (1973), and Gassicourt (1978), and for a fellowship year, 1980-81, to write the book. The text was finished at the Center for Advanced Study in the Visual Arts, National Gallery of Art, in the summer of 1981 . I am thankful for friends of skill and integrity, Lorna Price and Michael Cothren. Grants from the Getty Grant Program and the University of California Scientific Account have facilitated publication.

I presented a paper on the Vendôme research at the Kalamazoo medieval conference in 1973, under the auspices of the International Center of Medieval Art. My work on Gassicourt was first given at a symposium held in conjunction with the exhibition Medieval and Renaissance Stained Glass from New England Collections at the Busch-Reisinger Museum, Harvard University, 1978; both exhibition and symposium were funded by the National Endowment for the Humanities. Research on Evron was presented at the Corpus Vitrearum symposium hosted by the Metropolitan Museum of Art in 1982. Part of the research on Dol formed a section of a paper given at the College Art Association meeting in 1983, and papers discussing various examples of western French stained glass now in the United States were given at the International Glass Conference at Corning in 1982 and at the International Center of Medieval Art session at the Kalamazoo medieval conference in 1987 . Publications drawn from the research are cited in the notes as appropriate. 
Jean Lafond said that only in Normandy (the part of the west that mattered, to him) could the development of stained glass be charted from 1250 through the fourteenth century. I hope to have extended his vision and I hope to have established-as Robert Branner did so magisterially for the architecture of Burgundy and the arts of St Louis's Paris-the artistic validity and fascination of western French stained glass.

Meredith Parsons Lillich

Syracuse University, 1990 


\section{NOTE TO THE READER}

In this text, bay numbers for churches presently included in a recensement follow recensement volumes I (1978) and II (1981) of the Corpus Vitrearum France (CVFR I, CVFR II, q.v., Selected Bibliography, p. 405). Exceptions are: Chartres cathedral, for which Delaporte numbers are more universally available; and Saint-Père de Chartres, for which I use the numbering system used in my monograph The Stained Glass of Saint-Père de Chartres (Middletown, Conn.: 1978). The bay numbering system employed in illustrated plans is identified on each plan.

In the text, saints are referred to with English-style abbreviations: St Marguerite, St Peter, Sts Gervais and Protais. In monuments they are spelled: Sainte-Radegonde de Poitiers, Saint-Denis.

M. P. L 

The night is far spent, the day is at hand...

let us put on the armor of light.

-ST PAUL, EPISTLE TO THE ROMANS 13:12

xxix 
